Bangladesh J. Bot. 42(1): 55-63, 2013 (June)

\title{
EFFECTS OF WATERLOGGING ON ION ACCUMULATION AND SUGAR, PROTEIN AND PROLINE CONTENTS IN CORCHORUS CAPSULARIS L.
}

\author{
Dilruba Parvin ANd JL Karmoker* \\ Department of Botany, University of Dhaka, Dhaka-1000, Bangladesh
}

Key words: Waterlogging, Jute, Cation, Anion, Sugar, Protein, Proline

\begin{abstract}
Waterlogging decreased accumulation of $\mathrm{K}^{+}, \mathrm{Ca}^{2+}, \mathrm{Mg}^{2+}, \mathrm{NO}_{3}{ }^{-}$and $\mathrm{PO}_{4}{ }^{3-}$ but increased that of $\mathrm{Na}^{+}$and $\mathrm{Fe}^{2+}$ in the root, stem and leaves of jute (Corchorus capsularis L.). It increased the accumulation of sugar and proline contents but decreased that of protein as well as dry weight. The effect of waterlogging on ion transport, accumulation of metabolites and dry weight was discussed.
\end{abstract}

\section{Introduction}

Waterlogging induces reductive stress in the rhizosphere under field condition involving anomalies in metabolism, ion transport and growth activities. Waterlogging decreased accumulation of $\mathrm{K}^{+}$, $\mathrm{Na}$ and $\mathrm{P}$ but increased that of $\mathrm{Fe}$ and $\mathrm{Mn}$ in Lepidium latifolium and in some other plant (Chen et al. 2005, Mendoza et al. 2005, Milroy et al. 2009 and Khabaz-Saberi and Rengel 2010). Waterlogging increased concentration of $\mathrm{Na}^{+}$in Zea mays (Drew and Dikumwin 1985). It decreased concentration of $\mathrm{K}^{+}, \mathrm{Ca}^{2+}, \mathrm{Mg}^{2+}$ in wheat and in Pinus (Topa and Mcleod 1986).

Waterlogging decreased soluble sugar content in maize (Rai et al. 2004) but increased reducing sugar content in Vigna luteola (Sairam et al. 2009).

Waterlogging caused an increase in proline content in Casuarina and wheat (Olgun et al. 2008 and Carter et al. 2006). Under such stress the soluble protein content was increased in maize (Rai et al. 2004) but not in wheat (Olgun et al. 2008).

Corchorus capsularis is a moderate waterlogging tolerant species of jute but the mechanism of its adaptation under waterlogging condition with respect to ionic relation and biochemical changes under such stress is yet to be explored.

In the present study the effects of waterlogging on ion transport, metabolism and growth activities of Corchorus capsularis L .cv. D I54 were investigated.

\section{Materials and Methods}

Seeds of jute (Corchorus capsularis L. cv. DI54) was collected through the courtesy of Bangladesh Jute Research Institute, Dhaka.

Plants were grown in water culture in half-strength Hoagland solution (Hoagland and Arnon 1950). Seeds were germinated in purified quartz sand contained in earthern pot lined with polythene and seedlings were grown up to 15-day-old stage. Seedlings were further grown for another 21-day-old stage under anaerobic (treatment) or aerobic condition in a black painted plastic buckets with a lid having ten holes $(3 \mathrm{~cm}$ in diameter) containing 5 litre of nutrient solution. One seedling was inserted in each hole and the seedling was plugged with spongy foam

*Author for correspondence: <Jlkarmoker48@gmail.com>. 
for support. Solution was replaced after every 48 hrs. In control, solution was aerated continuously by passing air with an air compressor and in treatment anaerobic condition was imposed by supplying nitrogen gas.

Root, stem and leaf were collected in triplicate from three plants following waterlogging treatment.

$\mathrm{K}^{+}, \mathrm{Na}^{+}$and $\mathrm{NO}_{3}{ }^{-}$were extracted from dry tissue by boiling in a water bath $\mathrm{K}^{+}$and $\mathrm{Na}^{+}$in plant tissue were analyzed by flame photometer and $\mathrm{NO}_{3}{ }^{-}$was measured following Cataldo et al. (1975).

For the determination of $\mathrm{Ca}^{2+}, \mathrm{Mg}^{2+}, \mathrm{Fe}^{2+}$ and $\mathrm{PO}_{4}{ }^{3-}$, dry plant tissue was extracted by digesting in a mixture of $\mathrm{HNO}_{3}{ }^{-}$and $\mathrm{HCl}_{3} \mathrm{O}_{4}(4: 1)$ in a sand bath. $\mathrm{Ca}^{2+}, \mathrm{Mg}^{2+}, \mathrm{Fe}^{2+}$ were measured in the digest by atomic absorption spectrophotometer and $\mathrm{PO}_{4}{ }^{3-}$ was measured according to Bray and Kurtz (1945).

Reducing and total sugars were extracted by boiling fresh tissue in $80 \%$ ethanol. Reducing sugar was determined by Somogyi-Nelson method (Nelson 1944, Somogyi 1952). Total sugar was determined by phenol- $\mathrm{H}_{2} \mathrm{SO}_{4}$ method of Dubois et al. (1956).

Protein was extracted by homogeniging $1 \mathrm{~g}$ fresh tissue in chilled $2 \mathrm{mM} \mathrm{KH}_{2} \mathrm{PO}_{4}$ buffer $(\mathrm{pH}$ 7.5) with mortar and pestle. The homogenate was then centrifuged in cold with a refrigerated centrifuge at $3000 \mathrm{~g}$ for $2 \mathrm{~min}$ and the supernatant was collected. The pellet was suspended in further $2 \mathrm{ml}$ of buffer and centrifuged for $5 \mathrm{~min}$ at $3000 \mathrm{~g}$ and the supernatant was collected. The combined extract containing soluble protein was made up to $5 \mathrm{ml}$ with buffer. The pellet was resuspended in $5 \mathrm{ml}$ of buffer, the suspension represented insoluble protein. One $\mathrm{ml}$ of each of soluble and insoluble protein suspension was placed in separate centrifuge tubes and $5 \mathrm{ml}$ of $5 \%$ trichloroacetic acid was added to each of them. The protein was allowed to precipitate for $30 \mathrm{~min}$ and then centrifuged for $5 \mathrm{~min}$ at $3000 \mathrm{~g}$. The supernatant was discarded. The pellet was suspended in $1 \mathrm{ml}$ of distilled water. Protein was determined following Lowry et al. (1951).

Proline was extracted by homogeniging fresh tissue in $0.1 \mathrm{M}$ sulphosalicyclic acid. The homogenate was then centrifuged at $3000 \mathrm{~g}$ for $5 \mathrm{~min}$ and the supernatant was collected for determination of proline following Bates et al. (1973).

\section{Results and Discussion}

Waterlogging decreased $\mathrm{K}^{+}$accumulation in the root of $C$. capsularis (Fig. 1a). In the stem, accumulation of $\mathrm{K}^{+}$gradually decreased up to $23.3 \%$ (Fig. $1 \mathrm{~b}$ ) and that in the leaf, up to $32.78 \%$ from 7 - 21 day of waterlogging treatment (Fig. 1c). Waterlogging-induced inhibition of $\mathrm{K}^{+}$accumulation was also reported in wheat (Sakib et al. 2005).

Waterlogging increased $\mathrm{Na}^{+}$content in the root of jute from $7-21$ day of treatment (Fig. 2b). Accumulation of $\mathrm{Na}^{+}$in the stem and leaves were increased up to 43.2 and $53.95 \%$, respectively at 21 day of waterlogging treatment (Fig. 2b, c). Waterlogging also decreased $\mathrm{Na}^{+}$content in wheat (Setter et al. 2009).

Waterlogging decreased $\mathrm{Ca}^{2+}$ accumulation in the root from $9.79-35.77 \%$ at $7-2$-daytreatment (Fig. 3a). Similar gradual decrease in $\mathrm{Ca}^{2+}$ accumulation in almost same degree was observed in the stem and leaves at 7 - 21 days following waterlogging treatment (Fig. 3b, c). Similar decrease in $\mathrm{Ca}^{2+}$ accumulation in the shoot was observed in the leaf of Lepidium latifolium (Chen et al. 2005).

Waterlogging decreased $\mathrm{Mg}^{2+}$ accumulation in the root (Fig. 4a). In the stem and leaves, the accumulation of $\mathrm{Mg}^{2+}$ gradually decreased (Fig. 4b, c). $\mathrm{Mg}^{2+}$ accumulation decreased in Alnus rubra and Populus trichocarpa (Harrington 1987). 

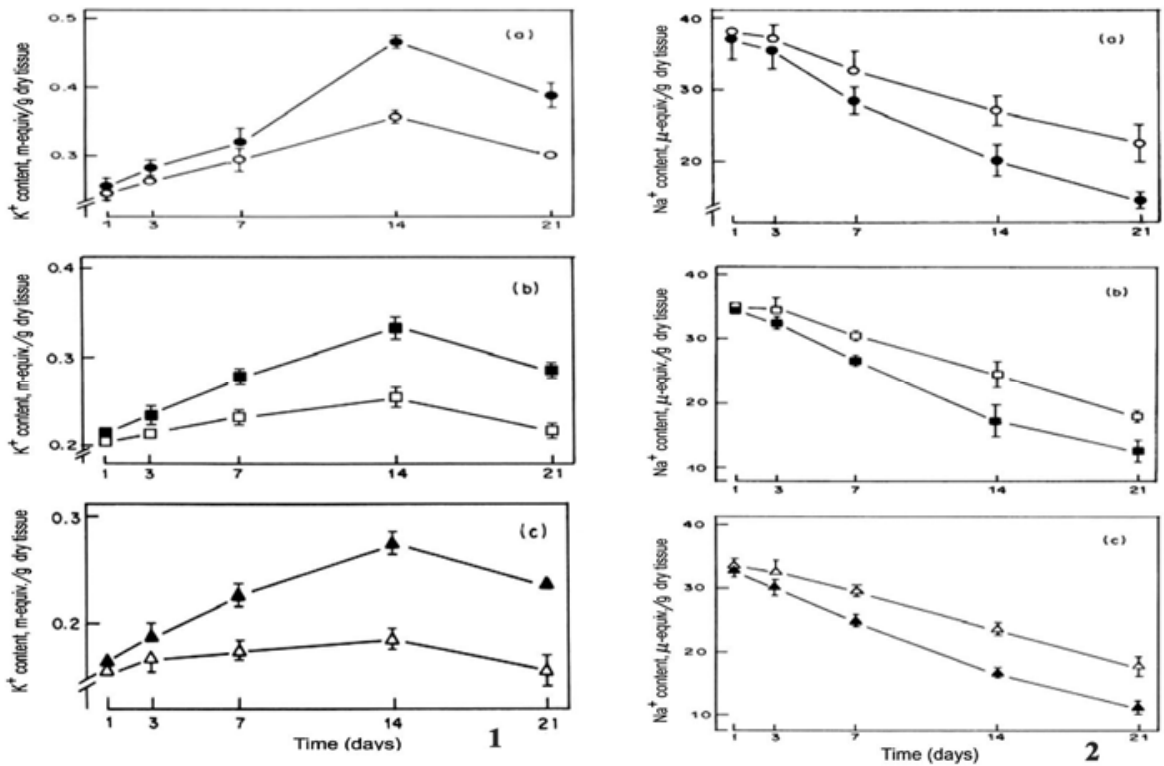

Fig. 1. The effect of waterlogging on accumulation of $\mathrm{K}^{+}$in (a) root (O), (b) stem ( $\square$ ) and (c) leaf ( $\Delta$ ) of C. capsularis grown in solution culture. Solid symbols represent control and open symbols represent waterlogging. Each value is the mean of three replicates \pm SE. Fig. 2. The effect of waterlogging on accumulation of $\mathrm{Na}^{+}$in the (a) root, (b) stem and (c) leaf. Otherwise as Fig.1.
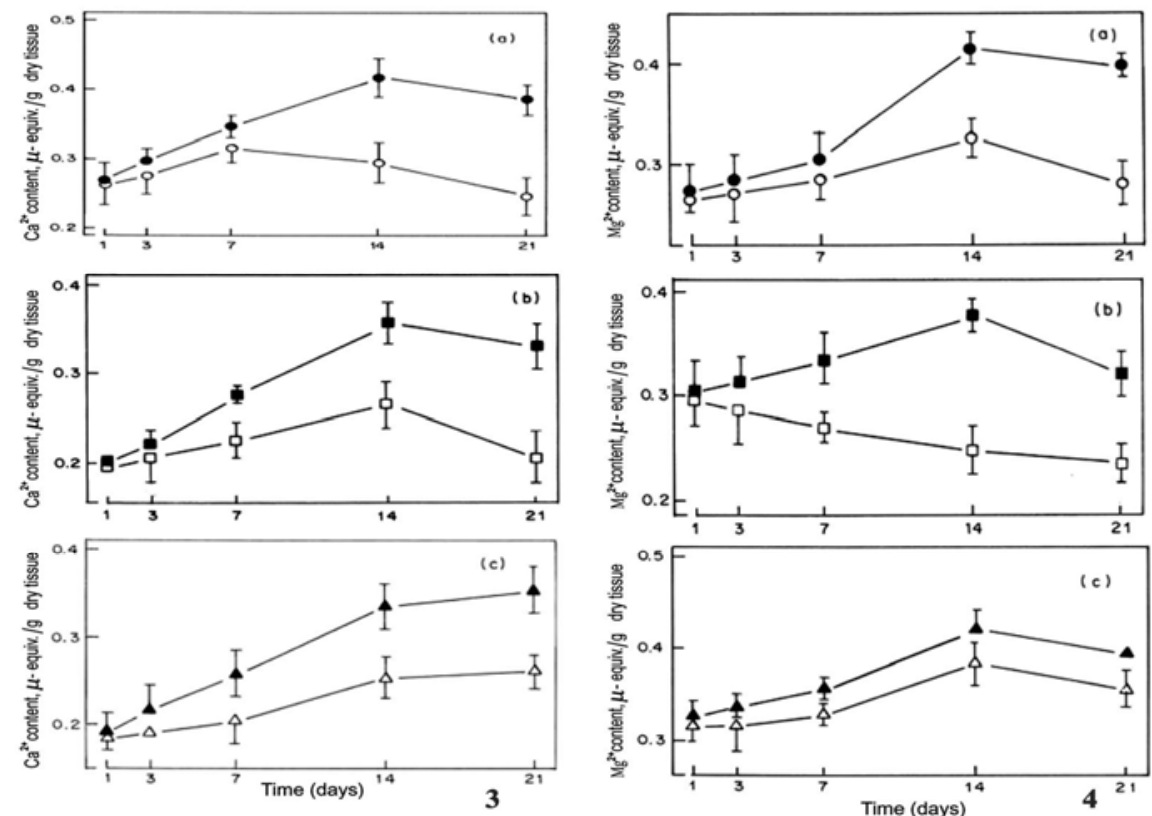

Fig. 3. The effect of waterlogging on accumulation of $\mathrm{Ca}^{2+}$ in the (a) root, (b) stem and (c) leaf. Otherwise as Fig.1. Fig. 4. The effect of waterlogging on accumulation of $\mathrm{Mg}^{2+}$ in the (a) root, (b) stem and (c) leaf. Otherwise as Fig.1. 
Waterlogging increased $\mathrm{Fe}^{2+}$ accumulation in the root, stem and leaf from 3 to 21-daytreatment which was in the magnitude of 10 to $17 \%$ of the control (Fig. 5a, b, c). It caused an increase in $\mathrm{Fe}^{2+}$ accumulation in Pinus leaf (Topa and Mcleod 1986).

Waterlogging decreased $\mathrm{NO}_{3}{ }^{-}$accumulation up to 4.92 to $26.89 \%$ from 7-21-day-treatment (Fig. 6a). It also gradually decreased accumulation of $\mathrm{NO}_{3}{ }^{-}$in the stem and leaf up to 21-daytreatment (Fig. 6b, c). Endogenous root nitrate in the shoot was strongly reduced under anaerobiosis due to mobilization of nitrate from the root to the shoot (Brandao and Sodek 2009).
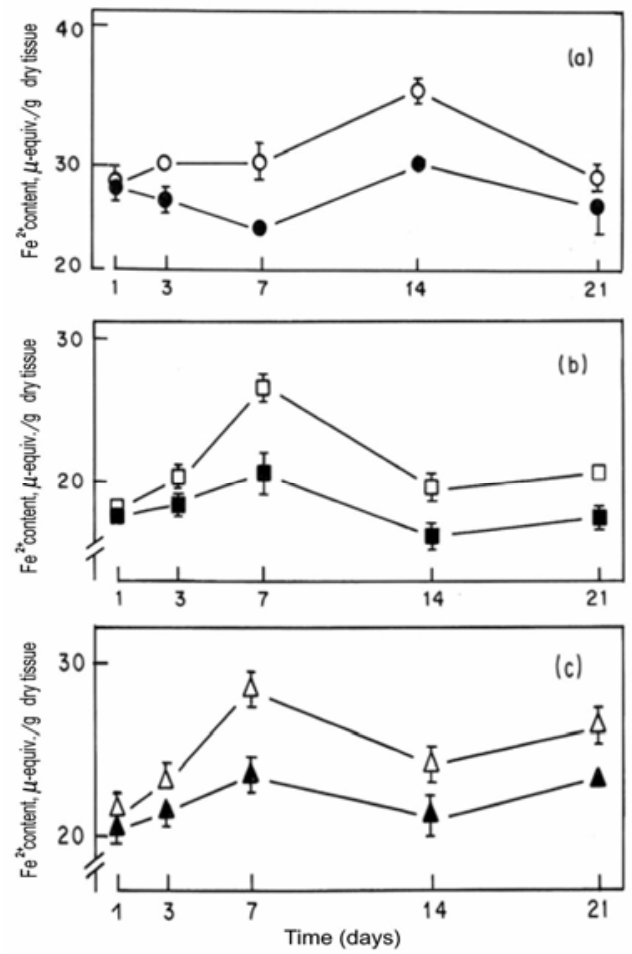

Fig. 5. The effect of waterlogging on accumulation of $\mathrm{Fe}^{2+}$ in the

(a) root, (b) stem and (c) leaf. Otherwise as Fig.1.

Accumulation of phosphate in the root decreased from 10.46 to $73.39 \%$ at 7 -21-daywaterlogging treatment (Fig. 7a). Similar degree of inhibition was observed in the stem and leaves following waterlogging treatment (Fig. 7b, c). There was a large decrease in concentration of $\mathrm{P}$ in the shoot of Lotus glaber (Mendoza et al. 2005).

Reducing sugar increased in the root from $8.69-46.51 \%$ at 1-21 days of waterlogging treatment (Fig. 8a) In the stem, reducing sugar gradually increased upto $41.09 \%$ at 21-day of waterlogging treatment (Fig. 8b). Similar increase in reducing sugar in the leaf was observed. The maximum increase was $24.42 \%$ at 21-day - waterlogging treatment (Fig. 8c). Kumutha et al. (2008) reported that waterlogging resulted in an increase in the accumulation of reducing sugar in the leaves of Cajanus cajan genotypes 'ICPL 84023' and 'ICP 301'. On the other hand, the reducing sugar content was decreased in the leaves of genotype of 'ICP 7035' and 'Pusa 207' of C. cajan under waterlogging treatment. 

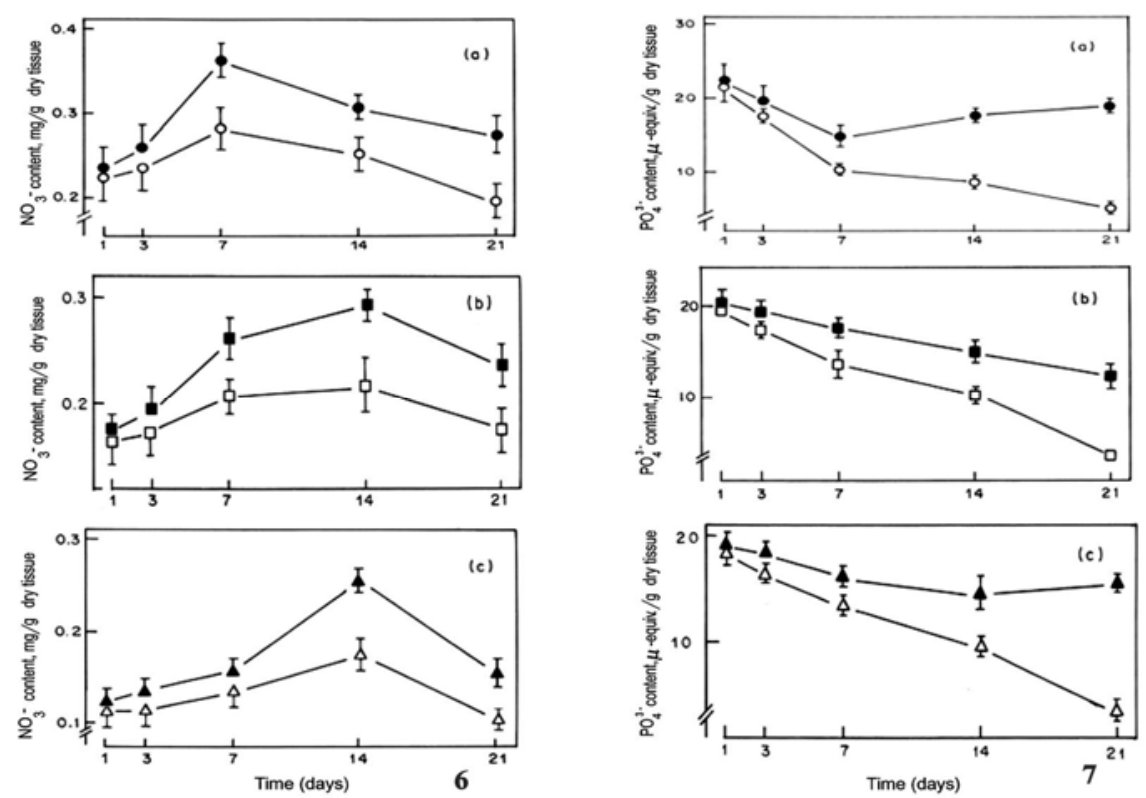

Fig. 6. The effect of waterlogging on accumulation of $\mathrm{NO}_{3}{ }^{-}$in the (a) root, (b) stem and (c) leaf. Otherwise as Fig. 1. Fig. 7. The effect of waterlogging on accumulation of $\mathrm{PO}_{4}{ }^{3-}$ in the (a) root, (b) stem and (c) leaf. Otherwise as Fig. 1.
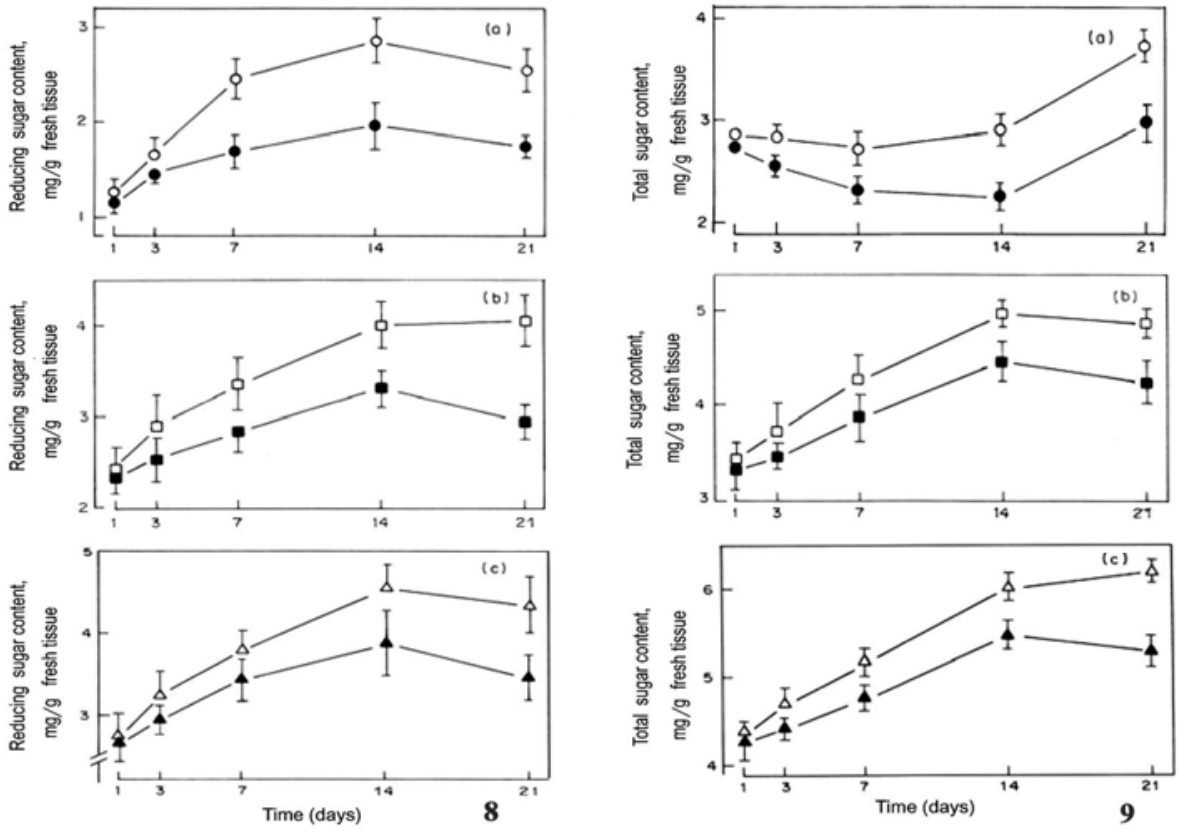

Fig. 8. The effect of waterlogging on accumulation of reducing sugar in the (a) root, (b) stem and (c) leaf. Otherwise as Fig. 1. Fig. 9. The effect of waterlogging on accumulation of total sugar in the (a) root, (b) stem and (c) leaf. Otherwise as Fig.1. 
Waterlogging increased total sugar in the root up to 5.51 to $24.08 \%$ at $1-21$ days of waterlogging treatment (Fig. 9a). In the stem and leaves, waterlogging increased the accumulation of total sugar up to 14.89 and $17.01 \%$ from 7 - 21 days of waterlogging treatment (Fig. 9b, c). On the contrary, waterlogging was found to decrease total sugar content in Vigna radiata genotype T44 (Sairam et al. 2009) in the root of Lotus japonica (Rocha et al. 2010). In Fraxinus angustifolia trees, the phloem-sucrose concentration was increased considerably during long-term waterlogging, but the concentration of that in the root was unaffected (Jaeger et al. 2009).

Waterlogging inhibited accumulation of soluble protein in the root (Fig. 10 a). Accumulation of soluble protein gradually decreased in the stem and leaves (Fig. 10 b, c). Similar inhibition of total soluble protein contents under waterlogging conditions was reported in cotton (Guo et al. 2010).Waterlogging decreased the accumulation of insoluble protein in the root, stem and leaves of jute (Fig. 11a, b, c). On the contrary, waterlogging was found to increase insoluble protein content in Brassica juncea (Ashraf and Mehmood 1990).
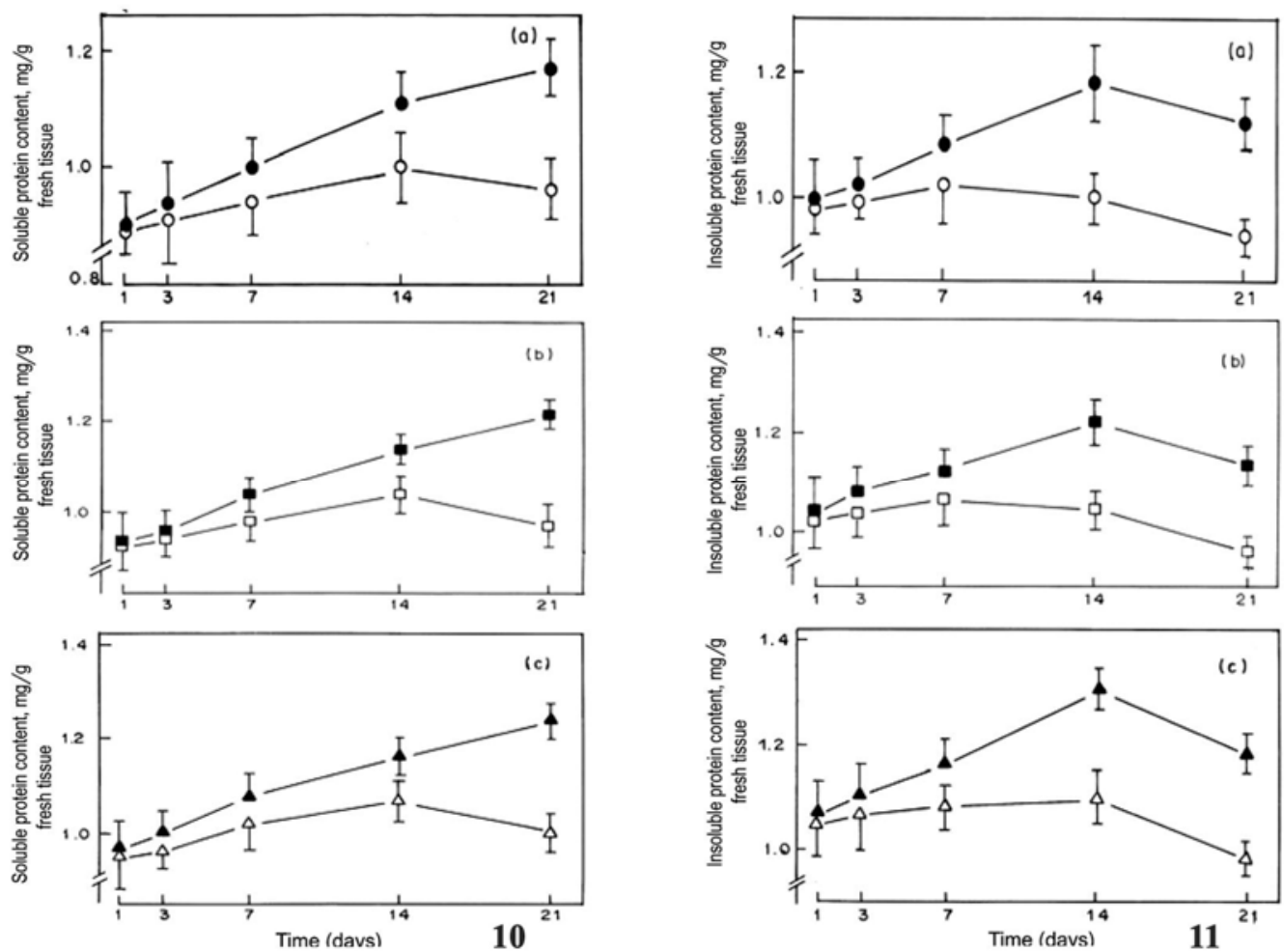

Fig. 10. The effect of waterlogging on accumulation of soluble protein in the (a) root, (b) stem and (c) leaf of $C$. capsularis grown in solution culture. Otherwise as Fig. 1. Fig. 11. The effect of waterlogging on accumulation of insoluble protein in the (a) root, (b) stem and (c) leaf of C. capsularis grown in solution culture. Otherwise as Fig.1.

Waterlogging increased accumulation of proline in the root by $50 \%$ at 3 days of waterlogging treatment (Fig. 12a). Similar increase in proline accumulation was observed in the stem and leaves of jute (Fig. 12b, c). Waterlogging caused a fourfold increase in the amount of proline content in vegetative and flowering stages in bambara groundnut (Vurayai et al. 2011) and also in the root and leaves of Solanum lycopersicum (Horchani et al. 2010). 
Waterlogging caused a slight decrease in dry matter content of root, stem and leaves at 1 to 21 days of treatment (Fig. 13a, b,c). Similarly, waterlogging was found to decrease dry weight of the root of C. olitorius and Hibiscus cannabinus. (Changdee et al. 2009).
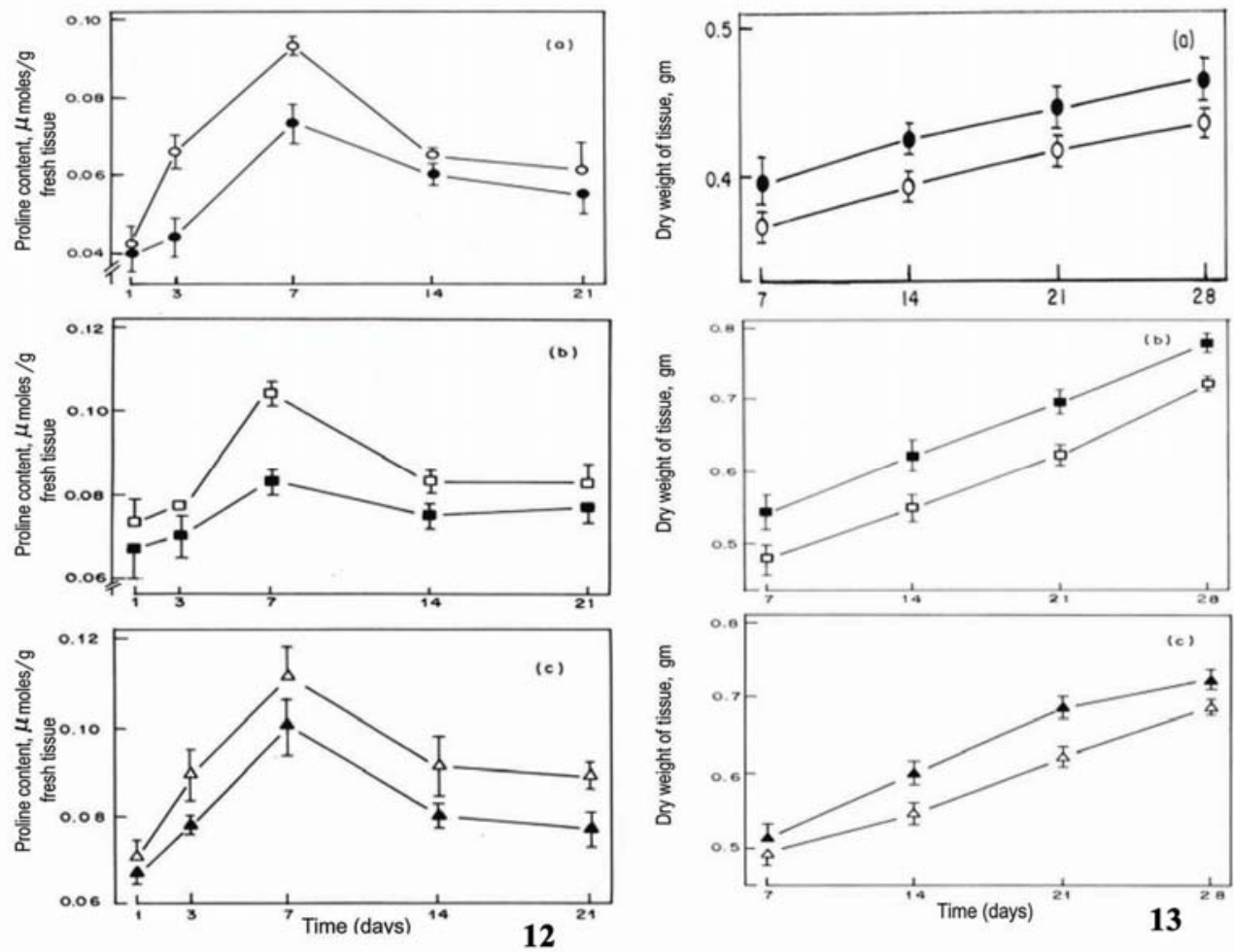

Fig. 12. The effect of waterlogging on accumulation of proline in the (a) root, (b) stem and (c) leaf. Otherwise as Fig. 1. Fig. 13. The effect of waterlogging on dry matter accumulation in the (a) root, (b) stem and (c) leaf. Otherwise as Fig. 1.

In conclusion, if the overall effects of waterlogging on ion transport, accumulation of proteins and amino acid are coordinated, a relationship between these parameters and growth may be established. For example, waterlogging decreased soluble protein accumulation. Soluble protein may also be used as respiratory substrate. Therefore, the decrease in soluble protein content might lead to shortage of energy supply which may have negative affect on accumulation and transport of ions. These adverse effects on inorganic nutrition and biochemical process might lead to the decrease in growth.

\section{References}

Ashraf M and Mehmood S 1990. Effects of waterlogging on growth and some physiological parameters of four Brassica species. Plant and Soil 121: 203-209

Brandao AD and Sodek L 2009. Nitrate uptake and metabolism by roots of soybean plants under oxygen deficiency. Braz. J. Plant Physiol. 21: 13-23.

Bates LS, Waldren RP and Teari D 1973. Rapid determination of free proline for water stress studies. Plant and Soil 39: 205-207. 
Bray RH and Kurtz LT 1945. Determination of total, organic and available forms of phosphorus in soils. Soil Sci. 59: 39-45.

Carter JL, Colmer TD and Veneklaas EJ 2006. Variable tolerance of wetland tree species to combined salinity and waterlogging is related to regulation of ion uptake and production of organic solutes. New Phytol. 169: 123-134.

Cataldo DA, Haaron M, Schrader LF and Youngs VL 1975. Rapid colorimetric determination of nitrate in plant tissue by titration of salicylic acid. Commun. Soil Sci. Plant Anal. 6: 71-81.

Changdee T, Polthanee A, Akkasaeng C and Morita S 2009. Effect of different waterlogging regimes on growth, some yield and roots development parameter in three fiber crops (Hibiscus cannabinus L., Hibiscus sabdariffa L. and Corchorus olitorius L.). Asian J. Plant Sci. 8: 515-525.

Chen H, Qualls RG and Blank RR 2005. Effects of soil flooding on photosynthesis, carbohydrate partitioning and nutrient uptake in the invasive exotic Lepidium latifolium. Aquatic Bot. 82: 250-268.

Dubois M, Gilles KA, Hemilton JK, Rebers PA and Smith F 1956. Colorimetric method for determination of sugars and related substance. Ann. Chem. 28: 350-356.

Drew MC and Dikumwin E 1985. Sodium exclusion from the shoots by roots of Zea mays (cv. LG 11) and its breakdown with oxygen deficiency. J. Expt. Bot. 36: 55-62.

Guo W-Q, Chen B-L, Liu R-X, Zhou Z-G 2010. Effects of nitrogen application rate on cotton leaf antioxidant enzyme activities and endogenous hormone contents under short-term waterlogging at flowering and boll forming stage. Chinese J. Applied Ecol. 21: 53-60.

Harrington CA 1987. Responses of red alder and black cottonwood seedlings to flooding. Physiol. Plant. 69: 35-48.

Hoagland DR and Arnon DI 1950. The water culture method for growing plants without soil. Calif. Agric. Expt. St. Circ. 347: 1-32.

Horchani F, Hajri R, Khayati H and Aschi-Smitis S 2010. Physiological responses of tomato plants to the combined effect of root hypoxia and NaCl-salinity. J. Phytol. 2: 36-46.

Jaeger C, Gessler A, Biller S, Rennenberg H and Kreuzwieser J 2009. Differences in C metabolism of ash species and provenances as a consequence of root oxygen deprivation by waterlogging. J. Expt. Bot. 60: $4335-4345$.

Khabaz-Saberi H and Rengel Z 2010. Aluminum, manganese, and iron tolerance improves performance of wheat genotypes in waterlogged acidic soils. J. Plant Nutr. Soil Sci. 173: 461-468.

Kumutha D, Sairam RK, Ezhilmathi K, Chinnusamy V and Meena RC 2008. Effects of waterlogging on carbohydrate metabolism in pigeon pea (Cajanus cajan L.): Upregulation of sucrose synthase and alcohol dehydrogenase. Plant Sci. 175: 706-716.

Lowry OH, Rosebrough NJ, Farr AL and Randall RJ 1951. Protein measurement with the Folin-Phenol reagent. J. Biol. Chem. 193: 266-275.

Mendoza R, Escudero V and Garcia I 2005. Plant growth, nutrient acquisition and mycorrhizal symbiosis of a waterlogging tolerant legume (Lotus glaber Mill.) in a saline-sodic soil. Plant and Soil 275: 305-315.

Milroy SP, Bange MP and Thongbai P 2009. Cotton leaf nutrient concentrations in response to waterlogging under field conditions. Field Crops Res. 113: 246-255.

Nelson N 1944. A photometric adaptation of the Somogyi method for determination of glucose. J. Biol. Chem. 153: 375-380.

Olgun M, Kumlay AM, Adiguzel MC and Caglar A 2008. Effects of waterlogging in wheat (T. aestivum L.). Acta Agric. Scandinavica, (Section B). Plant Soil Sci. 58: 193-198.

Rai RK, Srivastava JP and Shahi JP 2004. Effects of waterlogging on some biochemical parameters during early growth stages of maize. Ind. J. Plant Physiol. 9: 65-68.

Rocha M, Licausi L and Araujo WL 2010. Glycolysis and the TCA-cycle are linked by alanine aminotransferase during hypoxia induced by waterlogging of Lotus japonicus. Physiol. Plant. 152: 1501-1513. 
Sairam RK, Dharmark K, Chinnusamy V and Meena RK 2009. Waterlogging-induced increase in sugar mobilization, fermentation, and related gene expression in the roots of mung bean (Vigna radiata). $\mathrm{J}$. Plant Physiol. 166: 602-616.

Saqib M, Akhtar J and Qureshi RH 2005. $\mathrm{Na}^{+}$exclusion and salt resistance of wheat (Triticum aestivum) in saline waterlogged conditions are improved by the development of adventitious nodal roots and cortical root aerenchyma. Plant Sci. 169: 125-130.

Setter TL, Waters I, Sharma SK, Singh KN, Kilshreshtha N, Yaduvanshi NPS, Ram PC, Singh BN, Rane J, McDonald G, Khabaz-Saberi H, Biddulph TB, Wilson R, Barclay I, McLean R and Cakir M 2009. Review of wheat improvement for waterlogging tolerance in Australia and India: The importance of anaerobiosis and element toxicities associated with different soils. Ann. Bot. 103: 221-235.

Somogyi M 1952. Notes on sugar determination. J. Biol. Chem. 195: 19-23.

Topa MA and McLeod KW 1986. Response of Pinus clausa, Pinus serotina and Pinus taeda to anaerobic solution culture II. Changes in tissue nutrient concentration and net acquisition. Physiol. Plant. 68: 532539.

Vurayai R, Emongor V and Moseki B 2011. Physiological responses of bambar groundnut (Vigna subterranea L. Verdc) to short periods of water stress during different developmental stages. Asian J. Agric. Sci. 3: 37-43.

(Manuscript received on 27 November, 2012; revised on 23 April, 2013) 